\title{
Prospective Evaluation of Infection Episodes in Cancer Patients in a Tertiary Care Academic Center: Microbiological Features and Risk Factors for Mortality
}

\author{
Kanser Hastalarındaki Enfeksiyon Ataklarının Prospektif Değerlendirmesi: Mikrobiyolojik \\ Özellikler ve Mortalite için Risk Faktörleri
}

\author{
Nursel Çalık Başaran¹, Ergun Karaağaoğlu², Gülşen Hasçelik³, Mine Durusu Tanrı̈ver¹, Murat Akova4 \\ 1 Hacettepe University Faculty of Medicine, Department of Internal Medicine, Ankara, Turkey \\ 2 Hacettepe University Faculty of Medicine, Department of Biostatistics, Ankara, Turkey \\ ${ }^{3}$ Hacettepe University Faculty of Medicine, Department of Basic Microbiology, Ankara, Turkey \\ ${ }^{4}$ Hacettepe University Faculty of Medicine, Department of Infectious Diseases and Clinical Microbiology, Ankara, Turkey
}

\section{Abstract}

Objective: We aimed to determine the frequency, type, and etiology of infections and the risk factors for infections and mortality in hospitalized cancer patients.

Materials and Methods: We prospectively enrolled adult cancer patients hospitalized in the internal medicine wards of a tertiary care academic center between January and August 2004. Patients were followed during their hospitalization periods for neutropenia, infections, culture results, and mortality.

Results: We followed 473 cancer patients with 818 hospitalization episodes and 384 infection episodes in total. Seventy-nine percent of the infections were nosocomial, and febrile neutropenia (FN) was observed in 196 (51\%) of the infection episodes. Bacteremia was found in 29\% of FN episodes and in $8 \%$ of nonneutropenic patients. Gram-positive bacteria were the leading cause of bacteremia in both neutropenic and nonneutropenic cases (70\% and 58\%, respectively). Presence of an indwelling central catheter increased bacteremia risk by 3 -fold. The overall mortality rate was $17 \%$, whereas $34 \%$ of the patients with bloodstream infections died. Presence of bacteremia and advanced disease stage increased overall mortality by 6.1 -fold and 3.7-fold, respectively.

Conclusion: Nearly half of the cancer patients developed an infection during their hospital stays, with gram-positive bacteria being the predominant etiologic microorganisms. This demonstrates the changing trends in infections considering that, until 2004, gramnegative bacteria were the most predominant microorganisms among cancer patients in our institute.

Keywords: Febrile neutropenia, Cancer, Mortality, Risk factors

\section{$\ddot{O} \mathrm{z}$}

Amaç: Enfeksiyonlar, kanser hastalarında önde gelen morbidite ve mortaliteleri nedeni olmuşlardır. Bu çalışmada hastanede yatan kanser hastalarında enfeksiyonların sıklığını, tiplerini, etiyolojilerini ve enfeksiyon gelişimi ve mortalite için risk faktörlerini belirlemeyi amaçladık.

Gereç ve Yöntemler: Üçüncü basamak bir üniversite hastanesinin iç hastalıkları servislerinde 0cak-Ağustos 2004 tarihleri arasında izlenmiş olan erişkin kanser hastaları dahil edildi. Yatış süreleri boyunca nötropeni, enfeksiyonlar, kültür sonuçları ve mortalite açısından prospektif olarak izlendiler.

Bulgular: Toplam 473 kanser hastasının 818 hastaneye yatış atağı izlendi. Toplam 818 yatış atağı sırasında 384 (\%46) enfeksiyon atağı gözlendi- \%79'u nozokomiyaldi. Febril nötropeni (FN) tüm atakların 196'sında (\%51) görüldü. Bakteremi, FN ataklarının \%29'unda ve nötropenik olmayan hastaların \%8'inde görüldü. Gram-pozitifler hem nötropenik olan hem de olmayan hastalardaki bakteremilerin önde gelen etkeni olarak görüldü ( $\% 70$ ve $\% 58$, sırasıyla). Santral kateter varlığının bakteremi riskini 3 kat artırdığı görüldü. Toplam mortalite \%17 iken bakteremisi olan hastalarda mortalite \%34 saptandı. Bakteremi varlığı ve ileri evre hastalık toplam mortaliteyi, sırasıyla, 6, 1 ve 3,7 kat artırmaktaydı.

Sonuç: Hastanede yatan kanser hastalarının neredeyse yarısında en azından bir enfeksiyon gelişmektedir ve bu enfeksiyonlarda grampozitifler hakimdir. Bu bilgiler, 2004 yılına kadar kanser hastalarında en sık görülen mikroorganizmaların gram-negatif mikroorganizmalar olduğu göz önüne alındığında, enfeksiyonlarda değişen eğilimler olduğunu göstermektedir.

Anahtar Sözcükler: Febril nötropeni, Kanser, Mortalite, Risk faktörleri
Address for Correspondence/Yazışma Adresi: Nursel CALIK BASARAN, M.D.

Hacettepe University Faculty of Medicine, Department of Internal Medicine, Ankara, Turkey

Phone : +903123053029

E-mail : nurselcbasaran@gmail.com
Received/Geliş tarihi: May 25, 2015 Accepted/Kabul tarihi: January 11, 2016 


\section{Introduction}

Infections have become the leading cause of mortality and morbidity of cancer while supportive and curative treatment strategies prolong life $[1,2]$. Cancer and its treatment suppress the immune system, and long and recurrent hospitalizations predispose patients to various infections.

Predominant infectious pathogens have been variable in time with changing cancer treatment strategies, antibacterial prophylaxis practices, and emerging resistance patterns in bacteria. Until the 1980s, the leading microorganisms in cancer patients were enteric gram-negative bacteria and Pseudomonas aeruginosa. As of the 1980s, gram-positive bacteria became the most common pathogens in these patients $[1,3,4]$. However, recently, nonfermenting gram-negative bacteria have emerged as the leading pathogens in cancer patients.

It is important to know the risk factors for infections, changing epidemiology, and resistance patterns of pathogenic microorganisms for the proper management of infections in cancer patients. In this study, we aimed to determine the frequency, type, and etiology of infections and the risk factors for infections and mortality in hospitalized cancer patients.

\section{Materials and Methods}

\section{Study Design and Patients}

This study was done in the internal medicine wards of a tertiary care university hospital. The institutional review board approved the study and adult cancer patients hospitalized between January and August 2004 were enrolled and followed prospectively. Demographic data, cancer type and stage, previous stem cell transplantation history and type, comorbidities, and presence of antibacterial utilization in the previous month were recorded upon admission. Presence of indwelling catheters (central or peripheral venous, arterial, urinary, or drainage), presence of parenteral nutrition, requirement of intensive care unit and mechanical ventilation, therapy for cancer (chemotherapy, radiation, corticosteroids), vital signs, infections, antibiotic usage, culture results, and neutrophil counts were recorded throughout the admission episode. Descriptive data and further analyses were done based on the admission episodes unless otherwise specified. One patient might have had more than one admission. The infectious diseases department followed the patients and the researchers did not intervene in the diagnostic and therapeutic processes.

Neutropenia was defined as an absolute neutrophil count below $500 / \mathrm{mm}^{3}$ or below $<1000 / \mathrm{mm}^{3}$ and expected to decline rapidly. Neutropenic infections were classified as clinically or microbiologically documented infection, bloodstream infection (BSI), or fever of unknown origin [5]. Infections were classified as nosocomial according to the 1998 definitions of the Centers for Disease Control and Prevention [6]. Metastatic solid tumors, newly diagnosed hematological malignancies with poor prognosis, and relapsed or treatment-resistant hematological malignancies were defined as advanced disease stage. Corticosteroid use was defined as the use of prednisolone at a dose of $>20 \mathrm{mg} /$ day (or equivalent) or over a period of 10 days whatever the dose was. Antifungal prophylaxis was defined as oral fluconazole/itraconazole used in prophylactic doses.

\section{Microbiological Methods}

All the cultures were collected from different parts of the body according to the presumed infections. They were inoculated onto suitable media and incubated at $37{ }^{\circ} \mathrm{C}$ for $24-48 \mathrm{~h}$. Catheter cultures were studied quantitatively. For blood cultures, a BD BACTEC 9000 Blood Culture System (Becton Dickinson Diagnostic Systems, Sparks, MD, USA) was used. All the microorganisms were identified by gram staining, conventional microbiological tests (such as hemolysis, catalase, oxidase, and coagulase reaction), and the Phoenix System (Becton Dickinson Diagnostic Systems). Antibiotic susceptibility tests were conducted with the Phoenix System and for Streptococcus pneumoniae by E-test (AB BIODISK, Solna, Sweden). Results were evaluated according to the Clinical and Laboratory Standards Institute 2004 standards.

\section{Statistical Analysis}

Data were analyzed by SPSS 11.5 for Windows (SPSS Inc., Chicago, IL, USA). Distribution of data was analyzed by Kolmogorov-Smirnov test. Normally distributed data are presented as mean \pm standard deviation, while abnormally distributed data are presented as median (minimum-maximum). Categorical variables were compared by chi-square test and Fischer's exact test where appropriate, and continuous variables were analyzed by Student's t-test. Risk analysis was performed by Fisher's exact chi-square test and parameters that were found to be significant were introduced into a multivariate logistic regression model. Relative risk was computed for possible risk factors with $95 \%$ confidence interval and $p<0.05$ was accepted as statistically significant.

\section{Results}

During the study period, 473 cancer patients between 16 and 82 years of age were enrolled and 818 hospitalization episodes were followed prospectively. Of these patients, $286(60 \%)$ were male and the mean age was 51 years (16-82 years). Chronic diseases accompanying admission episodes were as follows: 4.8\% coronary artery disease, $2.7 \%$ chronic renal failure, $10.2 \%$ diabetes mellitus, and $13.4 \%$ hypertension. Solid organ cancer was seen in 254 (53\%) patients while the remaining had hematological diseases (Table 1). Hematopoietic stem cell transplantation (HSCT) was done in 49 patients with 63 
admission episodes (7.7\%) and half of them were allogeneic HSCTs.

In the course of 818 hospitalization episodes, a total of 384 $(46 \%)$ infection episodes were observed and $79 \%$ of these were nosocomial. Febrile neutropenia (FN) was observed in 126 patients having 196 (51\%) infection episodes. Acute myeloid leukemia was the most common underlying disease $(n=35,35 / 126,27 \%)$ in patients with FN. Mean duration of neutropenia was longer in patients with an infection (16.2 days) when compared to those without an infection (8.2 days) $(p=0.002)$. Bacteremia was found in $29 \%$ of FN episodes and in $8 \%$ of nonneutropenic infections $(p<0.05)$. Sites of infections in neutropenic and nonneutropenic patients are shown in Table 2. The mean hospitalization duration was three times longer for patients with infection ( $38 \pm 31$ days) when compared to the mean of the total hospitalization episodes $(13 \pm 23$ days).

\begin{tabular}{|c|c|c|c|}
\hline Patient Characteristics & & $\begin{array}{l}\text { All Patients } \\
(\mathrm{n}=473) \text { n }(\%)\end{array}$ & $\begin{array}{l}\text { Patients with Infection } \\
(n=272) n(\%)\end{array}$ \\
\hline Age (years)* & & $51 \pm 16$ & $51 \pm 16$ \\
\hline Male sex & & $286(60.5)$ & $161(59.2)$ \\
\hline Duration of hospitalization (days)* & & $13 \pm 23$ & $38 \pm 31$ \\
\hline \multicolumn{4}{|l|}{ Malignancy } \\
\hline \multirow[t]{10}{*}{ Hematological diseases } & & $219(46.3)$ & $158(58)$ \\
\hline & Non-Hodgkin lymphoma & $82(17)$ & 54 (19.9) \\
\hline & Acute myeloblastic leukemia & $43(9.1)$ & $36(13.2)$ \\
\hline & Acute lymphoblastic leukemia & $17(3.6)$ & $14(5.1)$ \\
\hline & Multiple myeloma & $35(7.4)$ & $23(8.5)$ \\
\hline & Hodgkin disease & $12(2.5)$ & $8(2.9)$ \\
\hline & Chronic lymphocytic leukemia & $13(2.8)$ & $6(2.2)$ \\
\hline & Chronic myelocytic leukemia & $5(1.1)$ & $5(1.8)$ \\
\hline & Myelodysplastic syndrome & $8(1.7)$ & $8(2.9)$ \\
\hline & Aplastic anemia & $4(0.8)$ & $4(1.5)$ \\
\hline \multirow[t]{20}{*}{ Solid organ malignancies } & & $254(53.7)$ & $114(41.9)$ \\
\hline & Lung cancer/malignant pleural mesothelioma & $69(14.6)$ & $30(11)$ \\
\hline & Colorectal carcinoma & $37(7.8)$ & $15(5.5)$ \\
\hline & Head and neck cancer & $24(5)$ & $5(1.8)$ \\
\hline & Esophagus/gastric cancer & $23(4.9)$ & $9(3.3)$ \\
\hline & Breast cancer & $16(3.4)$ & $8(2.9)$ \\
\hline & Cancer of unknown primary origin & $13(2.7)$ & $6(2.2)$ \\
\hline & Pancreas cancer & $9(1.9)$ & $5(1.8)$ \\
\hline & Ovarian cancer & $8(1.7)$ & $4(1.5)$ \\
\hline & Testicular cancer & $7(1.5)$ & $5(1.8)$ \\
\hline & Thyroid/adrenal/neuroendocrine tumor & $5(1.1)$ & $2(0.7)$ \\
\hline & Sarcoma & $5(1.1)$ & $4(1.5)$ \\
\hline & Malign mesenchymal tumor & $4(0.8)$ & $2(0.7)$ \\
\hline & Endometrium cancer & $3(0.6)$ & $2(0.7)$ \\
\hline & Cervical cancer & $4(0.8)$ & $3(1.1)$ \\
\hline & Bladder cancer & $3(0.6)$ & $3(1.1)$ \\
\hline & Prostate cancer & $1(0.2)$ & $1(0.4)$ \\
\hline & Renal cell cancer & $4(0.8)$ & $2(0.7)$ \\
\hline & Intracranial tumor & $3(0.6)$ & $3(1.1)$ \\
\hline & Malignant melanoma & $3(0.6)$ & $1(0.4)$ \\
\hline
\end{tabular}


Fluconazole as antifungal prophylaxis was given in $63(7.7 \%)$ episodes as a part of the stem cell transplantation regimen. Corticosteroids were used in 215 (26.4\%) of the admission episodes. Radiation therapy was performed in 5.1\% (42) of hospitalization episodes. Unfortunately, we had no data about granulocyte colony-stimulating factor use in this study.

Nonneutropenic episodes constituted $71.4 \%$ of all the hospitalization episodes and in $77.3 \%$ of these cases an immunosuppressive treatment, including corticosteroids, was used. As expected, there was an immunosuppressive treatment in $94 \%$ of neutropenic episodes $(p<0.001)$. Among the nonneutropenic episodes, infections were more frequently seen in those patients receiving any immunosuppressive treatment than in episodes with no immunosuppressive treatment $(p<0.001)$. However, there was no difference in terms of mortality $(p=0.111)$.

At least one pathogenic microorganism was isolated from culture specimens obtained from patients during 187 (48.6\%) infection episodes. Blood cultures were positive in $29.6 \%$ of all the patients and in $60.6 \%$ of neutropenic patients. Gram-negative microorganisms were the most common (51\%) isolates among all the specimens, whereas gram-positive microorganisms were the most common (65\%) among blood culture isolates (Table 3). Fungi were isolated in 5\% of all the specimens and 9\% of the specimens from neutropenic patients. When bacteremic episodes were considered, gram-positive bacteria were the leading cause in both neutropenic and nonneutropenic cases (70\% and 58\%, respectively; $p<0.05$ ) (Table 4).

\begin{tabular}{|l|l|}
\hline $\begin{array}{l}\text { Table 2. Distribution of infection sites in neutropenic and } \\
\text { nonneutropenic patients. }\end{array}$ \\
\hline Infection sites & $\mathbf{n} \%$ \\
\hline Neutropenic episodes (n=206) & $72(34)$ \\
\hline Fever of unknown origin & $59(29)$ \\
\hline Bloodstream infection & $14(7)$ \\
\hline $\begin{array}{l}\text { Microbiologically documented infection (other than } \\
\text { bloodstream) }\end{array}$ & $61(30)$ \\
\hline Clinical infection & \\
\hline Nonneutropenic episodes (n=279) & $94(3)$ \\
\hline Respiratory infection & $64(22.9)$ \\
\hline Urinary tract infection & $52(18)$ \\
\hline Gastrointestinal system infection & $42(15)$ \\
\hline Skin and soft tissue infection & $21(8)$ \\
\hline Bloodstream infection & $4(1.4)$ \\
\hline Central nervous system infection & $2(0.7)$ \\
\hline Skeletal system infection & \\
\hline $\begin{array}{l}\text { Some patients may have had more than one neutropenic episode within one hospital } \\
\text { admission. "n" refers to number of infection episodes and \% is the percentage within } \\
\text { neutropenic or nonneutropenic episodes. }\end{array}$ \\
\hline
\end{tabular}

The resistance patterns of Staphylococcus aureus, Staphylococcus epidermidis, Escherichia coli, Klebsiella spp., and Pseudomonas spp. are listed in Table 5. In neutropenic patients, rates of extended-spectrum $\beta$-lactamase (ESBL)producing E. coli and Klebsiella spp. were found to be high compared to nonneutropenic patients $(p<0.05)$.

\begin{tabular}{|c|c|c|}
\hline & $\begin{array}{l}\text { Blood } \\
\text { Cultures }\end{array}$ & $\begin{array}{l}\text { All } \\
\text { Cultures }\end{array}$ \\
\hline Name of microorganism & n $(\%)$ & n $(\%)$ \\
\hline Staphylococcus aureus & $8(5)$ & $26(4.8)$ \\
\hline Staphylococcus aureus (MR) & $2(1.2)$ & $9(1.6)$ \\
\hline Coagulase-negative staphylococci & $11(7)$ & $17(3.1)$ \\
\hline Coagulase-negative staphylococci (MR) & $67(42)$ & $103(19.2)$ \\
\hline Streptococcus pneumoniae & $1(0.6)$ & $7(1.3)$ \\
\hline Streptococcus viridans & $2(1.2)$ & $4(0.7)$ \\
\hline Streptococcus pyogenes & $3(1.9)$ & $1(0.1)$ \\
\hline Streptococcus agalactiae & $2(1.2)$ & $5(0.9)$ \\
\hline Enterococcus faecalis & $2(1.2)$ & $30(5.5)$ \\
\hline Enterococcus faecium & $3(1.9)$ & $9(1.6)$ \\
\hline Enterococcus gallinarum/casseliflavus & 0 & $2(0.3)$ \\
\hline Corynebacterium spp. & $1(0.6)$ & $2(0.3)$ \\
\hline Gram-positive bacteria: total & $102(65)$ & $215(40)$ \\
\hline Moraxella catarrhalis & 0 & $1(0.1)$ \\
\hline Haemophilus influenza & $1(0.6)$ & $8(1.4)$ \\
\hline Escherichia coli & $8(5)$ & $80(14.9)$ \\
\hline Escherichia coli (ESBL+) & $6(3.8)$ & $33(6.1)$ \\
\hline Klebsiella pneumoniae & $2(1.2)$ & $19(3.5)$ \\
\hline Klebsiella oxytoca & $4(2.5)$ & $17(3.1)$ \\
\hline Klebsiella pneumoniae (ESBL+) & $4(2.5)$ & $9(1.6)$ \\
\hline Klebsiella oxytoca (ESBL+) & 0 & $2(0.3)$ \\
\hline Proteus vulgaris & 0 & $7(1.3)$ \\
\hline Enterobacter spp. & $2(1.2)$ & $15(2.7)$ \\
\hline Salmonella spp. & $3(1.9)$ & $3(0.5)$ \\
\hline Pseudomonas aeruginosa & $11(7)$ & $49(9.1)$ \\
\hline Acinetobacter baumannii & $2(1)$ & $13(2.4)$ \\
\hline Other Acinetobacter spp. & 0 & $3(0.5)$ \\
\hline Stenotrophomonas maltophilia & $3(1.9)$ & $9(1.6)$ \\
\hline Aeromonas spp. & $1(0.6)$ & $3(0.5)$ \\
\hline Citrobacter spp. & 0 & $2(0.3)$ \\
\hline Gram-negative bacteria: total & $47(30)$ & $273(51)$ \\
\hline Candida albicans & $6(3.8)$ & $41(7.6)$ \\
\hline Candida tropicalis & 0 & $2(0.3)$ \\
\hline Trichosporon spp. & $2(1.2)$ & $2(0.3)$ \\
\hline Aspergillus spp. & 0 & $1(0.1)$ \\
\hline Candida glabrata/krusei & 0 & $2(0.3)$ \\
\hline Fungi: total & $8(5)$ & $48(9)$ \\
\hline
\end{tabular}


Possible risk factors for infection in cancer patients were analyzed by univariate analysis and then the risk factors found to increase the occurrence of an infection were introduced into a multivariate logistic regression model (Table 6). We found that advanced disease stage, neutropenia for more than 7 days, and radiation were related to an increased frequency of infection in cancer patients $(p<0.05)$. Presence of an indwelling central catheter increased bacteremia risk by 3 -fold (Table 6 ).

The overall mortality rate was $17 \%$, whereas $34 \%$ of patients with BSIs died $(p<0.05)$. Among patients with $\mathrm{FN}$, the mortality rate was $18.4 \%$, and the occurrence of a BSI increased the mortality rate to $41 \%$. Presence of bacteremia increased overall mortality 6.1 times and advanced disease stage increased overall mortality 3.7 times. On the other hand, usage of prophylactic antifungal therapy decreased mortality $3.3-$ fold, but the $p$-value was found to be statistically insignificant $(p=0.055)$
(Table 6). Comorbid chronic diseases had no significant effect on infection or mortality.

\section{Discussion}

This study is a landmark study to show the shift of infectious etiologies in cancer patients from gram-negative to grampositive bacteria. Afterwards, a long-term multicentric study was established in Turkey for microbiological surveillance of FN patients. Such surveillance studies are valuable to implement systemic changes in individual institutions and countries.

In this prospective observational study we found that $46 \%$ of all cancer patients developed at least one infection and $85 \%$ of neutropenic patients developed at least one FN attack during their index hospital stay. Among the neutropenic attacks, $65 \%$ were documented clinically or microbiologically, and the

Table 4. Isolates of blood cultures in neutropenic and nonneutropenic patients.

\begin{tabular}{|c|c|c|c|}
\hline Microorganisms & Neutropenic, n (\%) & Nonneutropenic, n (\%) & p-value \\
\hline Coagulase-negative staphylococci (MR) & $58(50.8)$ & $9(21)$ & $<0.05$ \\
\hline Coagulase-negative staphylococci & $6(5.3)$ & $5(12)$ & 0.4 \\
\hline Streptococcus pyogenes & $3(2.6)$ & 0 & \\
\hline Enterococcus faecalis & $3(2.6)$ & $1(2)$ & \\
\hline Enterococcus faecium & $2(1.75)$ & $2(4.6)$ & \\
\hline Viridans group streptococci & $1(0.9)$ & $1(2)$ & \\
\hline Streptococcus agalactiae & $1(0.9)$ & $1(2)$ & \\
\hline Corynebacterium spp. & $1(0.9)$ & 0 & \\
\hline Escherichia coli (ESBL+) & $4(3.5)$ & $2(4.6)$ & \\
\hline Pseudomonas aeruginosa & $6(5.3)$ & $5(12)$ & \\
\hline Klebsiella pneumoniae (ESBL+) & $4(3.5)$ & 0 & \\
\hline Klebsiella pneumoniae & $2(1.75)$ & 0 & \\
\hline Stenotrophomonas maltophilia & $3(2.6)$ & 0 & \\
\hline Enterobacter cloaca & $2(1.75)$ & 0 & \\
\hline Klebsiella oxytoca & $1(0.9)$ & $3(7)$ & \\
\hline Acinetobacter baumannii & $1(0.9)$ & $1(2)$ & \\
\hline Aeromonas spp. & $1(0.9)$ & 0 & \\
\hline Total & $114(100)$ & 43 (100) & $<0.05$ \\
\hline
\end{tabular}




\begin{tabular}{|c|c|c|c|c|c|}
\hline & Resistance & Total, n (\%) & Nonneutropenic, n (\%) & Neutropenic, n (\%) & p-value \\
\hline \multirow[t]{2}{*}{ Escherichia coli } & ESBL (-) & $80(70.7)$ & $72(75.7)$ & $8(44.4)$ & \\
\hline & $\operatorname{ESBL}(+)$ & $33(29.3)$ & $23(24.3)$ & $10(55.6)$ & $<0.05$ \\
\hline \multirow[t]{2}{*}{ Klebsiella spp. } & ESBL (-) & $36(76.5)$ & $30(85.7)$ & $6(50)$ & \\
\hline & ESBL (+) & $11(23.5)$ & $5(14.3)$ & $6(50)$ & $<0.05$ \\
\hline \multirow[t]{2}{*}{ Staphylococcus aureus } & MS & $26(74)$ & $18(72)$ & $8(80)$ & \\
\hline & MR & $9(26)$ & 7 (28) & $2(20)$ & NA \\
\hline \multirow[t]{2}{*}{ Staphylococcus epidermidis } & MS & $2(3.7)$ & $2(10.5)$ & $0(0)$ & \\
\hline & MR & $52(96.3)$ & $17(89.5)$ & $35(100)$ & NA \\
\hline \multirow[t]{2}{*}{ Pseudomonas aeruginosa } & MDR (-) & $23(71.8)$ & $18(75)$ & $5(62.5)$ & \\
\hline & MDR (+) & $9(28.2)$ & $6(25)$ & $3(37.5)$ & NA \\
\hline
\end{tabular}

\begin{tabular}{|c|c|c|c|c|c|c|}
\hline & \multicolumn{2}{|l|}{ Infection } & \multicolumn{2}{|c|}{ Bloodstream Infection } & \multicolumn{2}{|l|}{ Mortality } \\
\hline & $\operatorname{RR}(95 \% \mathrm{Cl})$ & p-value & $\operatorname{RR}(95 \% \mathrm{Cl})$ & p-value & $\operatorname{RR}(95 \% \mathrm{Cl})$ & p-value \\
\hline Duration of neutropenia $>7$ days & $3.9(1.6-9.5)$ & 0.002 & - & - & - & - \\
\hline Radiation & $3.5(1.2-7.6)$ & 0.017 & - & - & - & - \\
\hline Antifungal prophylaxis & - & - & - & - & $0.3(0.09-1.0)$ & 0.055 \\
\hline Bloodstream infection & - & - & - & - & $6.1(2.8-13.2)$ & $<0.001$ \\
\hline
\end{tabular}

BSI rate was $29 \%$ among the FN attacks, comparable to that reported in numerous other studies $[5,7,8,9]$. Compared to previous surveillance data from our hospital, both documented clinical infection and BSI rates were increased, which might be attributed to increased awareness of FN and appropriate blood culture techniques $[10,11]$. The definition of BSI may also have an influence on infection rates; the criteria used for skin flora organisms to be pathogens may be a reason for increased BSI rate.

Methicillin-resistant coagulase-negative staphylococci (MRCoNS) were the most commonly isolated microorganisms from overall and blood culture specimens. The predominance of grampositive bacteria and MR-CoNS in BSIs in this cohort was parallel to findings in the literature. In cancer patients BSIs were due to gram-negative enteric bacteria and Pseudomonas aeruginosa in the 1960s and 1970s, but by the middle of the 1980s grampositive bacteria had become predominant $[12,13]$. Memorial Sloan-Kettering Cancer Center reported that the incidence of gram-positive BSIs increased from 14\% to 23\% between 1977 and $1987[1,8]$. During the same time period, both the European Organisation for Research and Treatment of Cancer (EORTC) and the Febrile Neutropenia Study Group reported that 55\%-60\% of BSls were due to gram-positive microorganisms [14]. In 2003,
Wisplinghoff et al. reported that in cancer patients nosocomial BSIs in 32\% of neutropenic cases and 33\% of nonneutropenic cases were due to CoNS [3]. Srinivasan et al. reported that in stem cell transplantation recipients, gram-positive bacteria, and especially members of skin flora such as Staphylococcus epidermidis, were predominant in BSls [9]. Mikulska et al. reported the gram-positive to gram-negative ratio as 60\%:40\% in BSI infections of cancer patients [15]. In our study, the MR-CoNS ratio was the ratio between the blood cultures, so repetitive isolations from a patient should be kept in mind. We also accepted a CoNS as a pathogen when $\geq 1$ blood culture was positive in the presence of fever or hypothermia, hypotension, indwelling catheter, or antibiotics, which could differ from other studies in the literature [1].

Recent studies revealed that in hematological malignancies gram-negative microorganisms have again become the most relevant microorganisms in BSIs. Cattaneo et al. reported a predominance of gram-negative bacteria (57.3\%) in hematological malignancies between 2004 and 2010 [16]. Gudiol et al. reported that $49 \%$ of BSIs in hematological malignancies were due to gram-negative microorganisms and it was concluded that gram-positive microorganisms had decreased after quinolone prophylaxis [17]. A recently published 
paper by Trecarichi et al. also reported the shift from grampositive to gram-negative bacteria in BSIs in hematologic malignancies and again they pointed out the increasing resistance among gram-negative bacteria [18]. Several studies demonstrated gram-negative predominance either in blood or other specimen cultures in hematologic or solid cancer patients, with a frequency ranging between $24.7 \%$ and $75.8 \%$ in different geographic places with high resistance rates, including ESBLpositive Enterobacteriaceae, multidrug-resistant Pseudomonas aeruginosa, Acinetobacter spp., and Stenotrophomonas maltophilia [19,20,21,22]. According to surveillance data between 2005 and 2009 from our institution, gram-negative bacteria became the predominant BSI etiology in hematological malignancies with high resistance patterns [23]. Our study differs from these other studies in two major points: first, in our study, we followed both hematological and solid cancer patients, and second, we accepted at least one positive culture with CoNS in the presence of fever or central venous catheter. The growing resistance problems, especially among gramnegative pathogens, require special efforts in infection control measures and rational antibiotic usage in cancer patients.

In this study ESBL-positive E. coli (55\%) and Klebsiella spp. (50\%) were more frequent in neutropenic cases than nonneutropenic cases. A literature review revealed that ESBL positivity in cancer patients ranged from $12 \%$ to $75 \%$ for E. coli and K. pneumoniae in different studies $[23,24,25,26,27,28,29]$. It was also shown that ESBL positivity negatively affects mortality and morbidity $[26,30,31]$. Unfortunately, due to low case numbers, we could not analyze the mortality effect of resistant gram-negative bacteria.

We found that patients who were neutropenic for 7 or more days were prone to infection 3.9-fold more so than others. Poor prognosis and advanced stage solid or hematologic cancers were also related to an increased infection risk by 3.1-fold. Radiation was another risk factor for infection. This might be explained by the characteristics of the patient group that received radiotherapy: poor performance status, palliation in advanced disease, advanced age, or total body radiation prior to stem cell transplantation.

Indwelling central catheter was a risk factor for BSIs. In the last 30 years, increased use of persistent indwelling catheters has brought about an increased infection risk, especially for CoNS BSIs $[1,12,32,33]$. Moreover, BSI was a risk factor for mortality in our study. In previous studies mortality in cancer patients with BSIs ranged between 20\% and 35\% and this changed according to the pathogenic microorganisms $[21,34,35,36,37,38]$. This also points to the importance of implementing catheter bundles to decrease catheter-associated BSI rates.
Antifungal prophylaxis was part of the prophylaxis regimen in HSCT patients and it seemed to lower the mortality, although we could not show statistical significance. There are some reports showing azole-resistant breakthrough fungemia, but a recent study from the EORTC revealed that antifungal prophylaxis was protective in fungemia in cancer patients [39]. As there are various studies on different oral antifungal prophylaxes with different outcomes favoring posaconazole, itraconazole, or fluconazole use in high-risk patients, further studies are required about which drug to use for which patient and how long these drugs must be used $[40,41,42]$.

\section{Conclusion}

Nearly half of the cancer patients developed an infection during their hospital stays, with gram-positive bacteria being the predominant etiologic microorganisms. This demonstrates the changing trends in infections considering that, until 2004, gramnegative bacteria were the most predominant microorganisms among cancer patients in our institute. Each patient must be evaluated individually for risk factors, and while antibiotic treatment is being planned, current local surveillance data and the resistance patterns of the microorganisms should be taken into account along with individual risk factors.

\section{Acknowledgment}

A part of this study was presented as a poster presentation at the Febrile Neutropenia Symposium, February 2005, Ankara, Turkey, and the Interscience Conference on Antimicrobial Agents and Chemotherapy, December 2005, Washington, DC, USA.

\section{Ethics}

Ethics Committee Approval: LUT 05/15; Informed Consent: It was taken.

\section{Authorship Contributions}

Concept: Nursel Çalık Başaran, Ergun Karaağaoğlu, Gülşen Hasçelik, Mine Durusu Tanrı̈ver, Murat Akova; Design: Nursel Çalık Başaran, Ergun Karaağaoğlu, Gülşen Hasçelik, Mine Durusu Tanriöver, Murat Akova; Data Collection or Processing: Nursel Çalık Başaran, Ergun Karaağaoğlu, Gülşen Hasçelik, Mine Durusu Tanrı̈̈ver, Murat Akova; Analysis or Interpretation: Nursel Çalık Başaran, Ergun Karaağaoğlu, Gülşen Hasçelik, Mine Durusu Tanrı̈̈ver, Murat Akova; Literature Search: Nursel Çalık Başaran, Ergun Karaağaoğlu, Gülşen Hasçelik, Mine Durusu Tanrı̈ver, Murat Akova; Writing: Nursel Çalık Başaran, Ergun Karaağaoğlu, Gülşen Hasçelik, Mine Durusu Tanrı̈ver, Murat Akova.

Conflict of Interest: The authors of this paper have no conflicts of interest, including specific financial interests, relationships, and/or affiliations relevant to the subject matter or materials included. 


\section{References}

1. Koll BS, Brown AE. The changing epidemiology of infections at cancer hospitals. Clin Infect Dis 1993;17(Suppl 2):S322-328.

2. Soave R, Sepkowitz KZ. The immunocompromised host. In: Reese RE, Betts RF (eds). A Practical Approach to Infectious Diseases, 3rd ed. Boston, Little, Brown \& Co., 1991.

3. Wisplinghoff $H$, Seifert $H$, Wenzel RP, Edmond MB. Current trends in the epidemiology of nosocomial bloodstream infections in patients with hematological malignancies and solid neoplasms in hospitals in the United States. Clin Infect Dis 2003;36:1103-1110.

4. Pizzo PA. Management of fever in patients with cancer and treatmentinduced neutropenia. N Engl J Med 1993;328:1323-1332.

5. Serody JS. Fever in immunocompromised patients. N Engl J Med 2000;342:217-218.

6. Crowe MJ, Cooke EM. Review of case definitions for nosocomial infection-towards a consensus. Presentation by the Nosocomial Infection Surveillance Unit (NISU) to the Hospital Infection Liaison Group, subcommittee of the Federation of Infection Societies (FIS). J Hosp Infect 1998;39:3-11.

7. Klastersky J. Management of fever in neutropenic patients with different risks of complications. Clin Infect Dis 2004;39(Suppl 1):S32-37.

8. Madani TA. Clinical infections and bloodstream isolates associated with fever in patients undergoing chemotherapy for acute myeloid leukemia. Infection 2000;28:367-373.

9. Srinivasan A, Wang C, Srivastava DK, Burnette K, Shenep JL, Leung W, Hayden RT. Timeline, epidemiology, and risk factors for bacterial, fungal, and viral infections in children and adolescents after allogeneic hematopoietic stem cell transplantation. Biol Blood Marrow Transplant 2013;19:94-101.

10. Akova M, Akan H, Korten V, Biberoğlu K, Hayran M, Ünal S, Kars A, Kansu E. Comparison of meropenem with amikacin plus ceftazidime in the empirical treatment of febrile neutropenia: a prospective randomised multicentre trial in patients without previous prophylactic antibiotics. Meropenem Study Group of Turkey. Int J Antimicrob Agents 1999;13:15-19.

11. Erman $M$, Akova $M, A$ kan $H$, Korten $V$, Ferhanoğlu B, Köksal I, Çetinkaya $Y$, Uzun Ö, Ünal S; Febrile Neutropenia Study Group of Turkey. Comparison of cefepime and ceftazidime in combination with amikacin in the empirical treatment of high-risk patients with febrile neutropenia: a prospective, randomized, multicenter study. Scand J Infect Dis 2001;33:827-831.

12. Gonzalez-Barca E, Fernandez-Sevilla A, Carratala J, Granena A, Gudiol F. Prospective study of 288 episodes of bacteremia in neutropenic cancer patients in a single institution. Eur J Clin Microbiol Infect Dis 1996;15:291296.

13. Whimbey E, Kiehn TE, Brannon P, Blevins A, Armstrong D. Bacteremia and fungemia in patients with neoplastic disease. Am J Med 1987;82:723-730.

14. EORTC International Antimicrobial Therapy Cooperative Group. Grampositive bacteraemia in granulocytopenic cancer patients. Eur J Cancer 1990;26:569-574.

15. Mikulska M, Del Bono V, Raiola AM, Bruno B, Gualandi F, Occhini D, di Grazia C, Frassoni F, Bacigalupo A, Viscoli C. Blood stream infections in allogeneic hematopoietic stem cell transplant recipients: reemergence of Gram-negative rods and increasing antibiotic resistance. Biol Blood Marrow Transplant 2009;15:47-53.

16. Cattaneo C, Antoniazzi F, Casari S, Ravizzola G, Gelmi M, Pagani C, D'Adda M, Morello E, Re A, Borlenghi E, Manca N, Rossi G. P. aeruginosa bloodstream infections among hematological patients: an old or new question? Ann Hematol 2012;91:1299-1304.

17. Gudiol C, Bodro M, Simonetti A, Tubau F, Gonzalez-Barca E, Cisnal M, Domingo-Domenech $E$, Jimenez $L$, Carratala J. Changing aetiology, clinical features, antimicrobial resistance, and outcomes of bloodstream infection in neutropenic cancer patients. Clin Microbiol Infect 2013;19:474-479.

18. Trecarichi EM, Pagano L, Candoni A, Pastore D, Cattaneo C, Fanci R, Nosari A, Caira M, Spadea A, Busca A, Vianelli N, Tumbarello M; HeMABIS RegistrySEIFEM Group, Italy. Current epidemiology and antimicrobial resistance data for bacterial bloodstream infections in patients with hematologic malignancies: an Italian multicentre prospective survey. Clin Microbiol Infect 2015;21:337-343.

19. Chen CY, Tsay W, Tang JL, Tien HF, Chen YC, Chang SC, Hsueh PR. Epidemiology of bloodstream infections in patients with haematological malignancies with and without neutropenia. Epidemiol Infect 2010;138:1044-1051.

20. Ghosh I, Raina V, Kumar L, Sharma A, Bakhshi S, Thulkar S, Kapil A. Profile of infections and outcome in high-risk febrile neutropenia: experience from a tertiary care cancer center in India. Med Oncol 2012;29:1354-1360.

21. Samonis G, Vardakas KZ, Maraki S, Tansarli GS, Dimopoulou D, Kofteridis DP, Andrianaki AM, Falagas ME. A prospective study of characteristics and outcomes of bacteremia in patients with solid organ or hematologic malignancies. Support Care Cancer 2013;21:2521-2526.

22. Poon LM, Jin J, Chee YL, Ding Y, Lee YM, Chng WJ, Chai LY, Tan LK, Hsu LY. Risk factors for adverse outcomes and multidrug-resistant Gramnegative bacteraemia in haematology patients with febrile neutropenia in a Singaporean university hospital. Singapore Med J 2012;53:720-725.

23. Kara Ö, Zarakolu $P$, Aşçığlu $S$, Etgül $S, U z B$, Büyükaşık Y, Akova M. Epidemiology and emerging resistance in bacterial bloodstream infections in patients with hematologic malignancies. Infect Dis (Lond) 2015;47:686693.

24. Gudiol C, Tubau F, Calatayud L, Garcia-Vidal C, Cisnal M, Sanchez-Ortega I, Duarte R, Calvo M, Carratala J. Bacteraemia due to multidrug-resistant Gram-negative bacilli in cancer patients: risk factors, antibiotic therapy and outcomes. J Antimicrob Chemother 2011;66:657-663.

25. Kim SH, Kwon JC, Choi SM, Lee DG, Park SH, Choi JH, Yoo JH, Cho BS, Eom KS, Kim YJ, Kim HJ, Lee S, Min CK, Cho SG, Kim DW, Lee JW, Min WS. Escherichia coli and Klebsiella pneumoniae bacteremia in patients with neutropenic fever: factors associated with extended-spectrum beta-lactamase production and its impact on outcome. Ann Hematol 2013;92:533-541.

26. Trecarichi EM, Tumbarello M, Spanu T, Caira M, Fianchi L, Chiusolo P, Fadda G, Leone G, Cauda R, Pagano L. Incidence and clinical impact of extendedspectrum- $\beta$-lactamase (ESBL) production and fluoroquinolone resistance in bloodstream infections caused by Escherichia coli in patients with hematological malignancies. J Infect 2009;58:299-307.

27. Wang SS, Lee NY, Hsueh PR, Huang WH, Tsui KC, Lee HC, Wu CJ, Chang CM, Huang $\mathrm{CC}$, Huang $\mathrm{CF}$, Ko WC. Clinical manifestations and prognostic factors in cancer patients with bacteremia due to extended-spectrum $\beta$-lactamaseproducing Escherichia coli or Klebsiella pneumoniae. J Microbiol Immunol Infect 2011;44:282-288.

28. Mikulska M, Viscoli C, Orasch C, Livermore DM, Averbuch D, Cordonnier C,

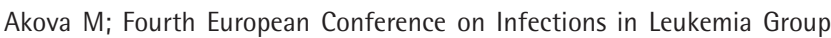
(ECIL-4), a joint venture of EBMT, EORTC, ICHS, ELN and ESGICH/ESCMID. Aetiology and resistance in bacteraemias among adult and paediatric haematology and cancer patients. J Infect 2014;68:321-331.

29. Zarakolu P, Metan G, Hasçelik G, Akova M. Prevalence of extended-spectrum beta-lactamases in nosocomial Escherichia coli and Klebsiella spp. strains isolated from blood cultures. Mikrobiyol Bul 2007;41:579-584a (in Turkish with English abstract).

30. Du B, Long $Y$, Liu $H$, Chen $D$, Liu $D, X u Y$, Xie X. Extended-spectrum beta-lactamase-producing Escherichia coli and Klebsiella pneumoniae bloodstream infection: risk factors and clinical outcome. Intensive Care Med 2002;28:1718-1723.

31. Kang Cl, Chung DR, Ko KS, Peck KR, Song JH; Korean Network for Study of Infectious Diseases. Risk factors for infection and treatment outcome of extended-spectrum $\beta$-lactamase-producing Escherichia coli and Klebsiella pneumoniae bacteremia in patients with hematologic malignancy. Ann Hematol 2012;91:115-121.

32. Eggimann $\mathrm{P}, \mathrm{Sax} H$, Pittet D. Catheter-related infections. Microbes Infect 2004;6:1033-1042.

33. Rosa RG, Goldani LZ, dos Santos RP. Risk factors for multidrug-resistant bacteremia in hospitalized cancer patients with febrile neutropenia: a cohort study. Am J Infect Control 2014;42:74-76. 
34. Anatoliotaki M, Valatas $V$, Mantadakis E, Apostolakou H, Mavroudis D, Georgoulias V, Rolston KV, Kontoyiannis DP, Galanakis E, Samonis G. Bloodstream infections in patients with solid tumors: associated factors, microbial spectrum and outcome. Infection 2004;32:65-71.

35. Mrázová-Studená M, Drgona L, Spánik S, Krúpová I, Baláz M, Pichna P, Koren P, Sufliarsky J, Mardiak J, Kunová A, Trupl J, Krcméry V Jr. Bacteremia in neutropenic versus nonneutropenic cancer patients: etiology and outcome in 401 episodes. Neoplasma 1997;44:314-318.

36. Velasco E, Byington R, Martins CA, Schirmer M, Dias LM, Goncalves VM. Comparative study of clinical characteristics of neutropenic and nonneutropenic adult cancer patients with bloodstream infections. Eur J Clin Microbiol Infect Dis 2006;25:1-7.

37. Marin M, Gudiol C, Ardanuy C, Garcia-Vidal C, Jimenez L, DomingoDomenech $E$, Perez FJ, Carratala J. Factors influencing mortality in neutropenic patients with haematologic malignancies or solid tumours with bloodstream infection. Clin Microbiol Infect 2015;21:583-590.

38. Marin M, Gudiol C, Garcia-Vidal C, Ardanuy C, Carratala J. Bloodstream infections in patients with solid tumors: epidemiology, antibiotic therapy, and outcomes in 528 episodes in a single cancer center. Medicine (Baltimore) 2014;93:143-149.
39. Cornely OA, Gachot B, Akan H, Bassetti M, Uzun O, Kibbler C, Marchetti O, de Burghgraeve P, Ramadan S, Pylkkanen L, Ameye L, Paesmans M, Donnelly JP; EORTC Infectious Diseases Group. Epidemiology and outcome of fungemia in a cancer cohort of the Infectious Diseases Group (IDG) of the European Organization for Research and Treatment of Cancer (EORTC 65031). Clin Infect Dis 2015;61:324-331.

40. Chan TS, Marcella SW, Gill H, Hwang YY, Kwong YL. Posaconazole versus fluconazole or itraconazole for prevention of invasive fungal diseases in patients with acute myeloid leukemia or myelodysplastic syndrome: a costeffectiveness analysis in an Asian teaching hospital. J Med Econ 2016;19:77-83.

41. El-Cheikh J, Crocchiolo R, Vai A, Furst S, Bramanti S, Sarina B, Granata A, Faucher C, Mohty B, Harbi S, Bouabdallah R, Vey N, Santoro A, Chabannon C, Castagna L, Blaise D. Comparison of three distinct prophylactic agents against invasive fungal infections in patients undergoing haploidentical hematopoietic stem cell transplantation and post-transplant cyclophosphamide. Mediterr J Hematol Infect Dis 2015;7:e2015048.

42. Bow EJ, Vanness DJ, Slavin M, Cordonnier C, Cornely OA, Marks DI, Pagliuca A, Solano C, Cragin L, Shaul AJ, Sorensen S, Chambers R, Kantecki M, Weinstein D, Schlamm H. Systematic review and mixed treatment comparison meta-analysis of randomized clinical trials of primary oral antifungal prophylaxis in allogeneic hematopoietic cell transplant recipients. BMC Infect Dis 2015;15:128. 